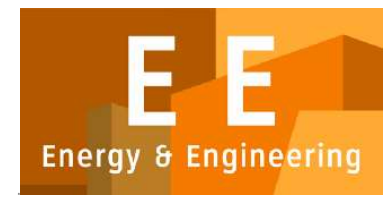

PAPER - OPEN ACCESS

\title{
Kajian Ecobrick Sebagai Pembentuk Pintu
}

\author{
Author $\quad$ : Novrial dan M. Rizky Anugraha \\ DOI $\quad: 10.32734 /$ ee.v3i1.852 \\ Electronic ISSN $\quad: 2654-704 X$ \\ Print ISSN : $2654-7031$
}

Volume 3 Issue 1 - 2020 TALENTA Conference Series: Energy \& Engineering (EE)

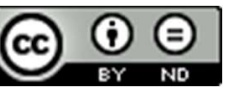

This work is licensed under a Creative Commons Attribution-NoDerivatives 4.0 International License.

Published under licence by TALENTA Publisher, Universitas Sumatera Utara

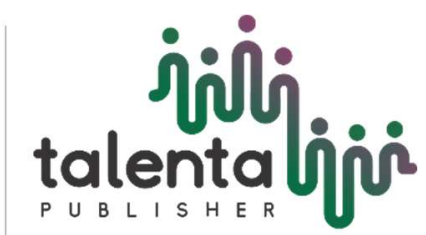




\title{
jibili (1) \\ EE Conference Series 03 (2020) \\ TALENTA Conference Series
}

$P U B L I S H E R$
Available online at https://talentaconfseries.usu.ac.id/ee

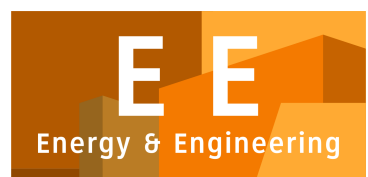

\section{Kajian Ecobrick Sebagai Pembentuk Pintu}

\author{
Ecobrick Study as a Door Shaper \\ Novrial $^{1} 1$, M. Rizky Anugraha ${ }^{1}$ \\ ${ }^{I}$ Departemen Arsitektur, Fakultas Teknik Universitas Sumatera Utara, Jalan. Perpustakaan, Kampus USU Gedung D, Padang Bulan, Medan Baru, \\ Kota Medan, Sumatera Utara 20155, Indonesia \\ *novrial@usu.ac.id, anugrahamrizky@gmail.com
}

\begin{abstract}
Abstrak
Plastik memiliki peran penting dalam kehidupan manusia. Hampir semua komponen dalam kehidupan manusia di zaman modern menggunakan plastik. Seiring dengan bertambahnya jumlah penduduk, penggunaan plastik juga meningkat. Hal ini tidak disertai dengan penanganan sampah plastik yang memadai. Permasalahan sampah plastik dapat berdampak negatif terhadapap manusia dan lingkungan. Beberapa upaya dilakukan untuk menangani permasalahan sampah plastik. Beberapa upaya penanganan sampah plastik membutuhkan biaya yang besar dan dapat mencemari lingkungan, sehingga diperlukan solusi yang aman bagi lingkungan dan menggunakan biaya yang murah. Dalam sudut pandang arsitektur, permasalah sampah dapat diatasi melalui arsitektur hijau. Arsitektur hijau dapat diwujudkan dengan penggunaan material dan metode yang sesuai dengan prinsip arsitektur hijau. Salah satu material yang sesuai dengan prinsip arsitektur hijau adalah material daur ulang (recycle). Ecobrick merupakan material hasil daur ulang (recycle). Ecobrick dapat mengurangi jumlah sampah plastik dan dapat digunakan sebagai bata untuk berbagai kebutuhan. Dalam penggunaannya, ecobrick dapat menjadi elemen dalam arsitektur. Ecobrick memiliki potensi sebagai material pengisi elemen pintu. Penelitian ini dilakukan untuk mengkaji ecobrick sebagai material pembentuk elemen pintu.
\end{abstract}

Kata kunci: ecobrick; material; pintu, recycle

\begin{abstract}
Plastic has an important role in human life. Almost all components in human life in modern times use plastic. As the population grows, the use of plastic also increases. This is not accompanied by adequate handling of plastic waste. The problem of plastic waste can have a negative impact on people and the environment. Several attempts were made to deal with the problem of plastic waste. Some plastic waste handling efforts require large costs and can pollute the environment, so we need a solution that is safe for the environment and uses low cost. From an architectural point of view, waste problems can be overcome through green architecture. Green architecture can be realized by the use of materials and methods that are in accordance with the principles of green architecture. One material that is in accordance with the principles of green architecture is recycled material. Ecobrick is a recycled material. Ecobrick can reduce the amount of plastic waste and can be used as a brick for various needs. In its use, ecobrick can be an element in architecture. Ecobrick has the potential as a filling material for door elements. This research was conducted to examine the ecobrick as a material forming the door element.
\end{abstract}

Keywords: ecobrick; material; door, recycle

(C) 2020 The Authors. Published by TALENTA Publisher Universitas Sumatera Utara 


\section{Pendahuluan}

Plastik memiliki peran penting dalam dimensi lingkungan, sosial, dan ekonomi. Gaya hidup modern tidak akan dapat diwujudkan tanpa plastik. Plastik memenuhi kebutuhan sosial dengan berbagai produk [14]. Seiring dengan meningkatnya jumlah populasi manusia, kebutuhaan akan plastik juga meningkat. Hal ini juga meningkatkan permasalahan sampah, terkhusus sampah plastik. Timbunan sampah padat sebagian besar berasal dari sampah plastik. Sekitar 10 persen sampah padat adalah plastik. Sampah yang berada di daratan, pantai atau lautan yang merupakan sampah plastik mencapai 80 persen bahkan lebih [2].

Manajemen sampah berhubungan dengan dampak lingkungan dan ekonomi. Pada tingkat lokal dan regional, pengumpulan sampah yang tidak memadai, pembuangan yang tidak tepat dan fasilitas yang tidak layak memiliki dampak negatif pada lingkungan dan kesehatan publik. Pada tingkat global, sampah padat dapat berkontribusi pada perubahan iklim dan menjadi salah satu sumber polusi di lautan. [6].

Hingga saat ini, ada tiga metode pembuangan sampah pada skala besar, yaitu tempat pembuangan akhir (TPA), pembakaran dan daur ulang. Setiap teknik memiliki kekurangan dan dampak. TPA dan pembakaran menghasilkan polutan berbahaya pada lingkungan. Dan TPA juga membutuhkan lahan yang luas. Daur ulang relatif tidak efisien dan mengurangi kualitas polimer yang dihasilkan. Daur ulang juga kurang efektif pada pembiayaan dan memiliki insentif yang kurang dari pembuatan fasilitas daur ulang [23]. Pendekatan manusia dalam produksi, penggunaan dan pembuangan sampah plastik tidak berkelanjutan. Hal ini dapat membahayakan kehidupan hewan liar dan kesehatan manusia [19].

Dalam sudut pandang arsitektur, permasalah sampah dapat diatasi melalui arsitektur hijau. Arsitektur hijau menghasilkan manfaat pada lingkungan, sosial, dan ekonomi [15]. Arsitektur hijau dapat diwujudkan dengan penggunaan material dan metode yang sesuai dengan prinsip arsitektur hijau. Ada empat manfaat dari penggunaan material bangunan dan metode konstruksi hijau. Pertama, metode konstruksi hijau dapat melestarikan sumber daya alam dan mengurangi sampah yang dihasilkan dari pembongkaran struktur lama dengan menggunakan kembali (reuse) dan daur ulang (recycle) meterial bangunan yang sudah ada. Kedua, konstruksi hijau menjaga sumber daya alam dengan menggunakan material yang sudah ada. Ketiga, konstruksi hijau dapat mengurangi energi yang dibutuhkan dalam konstruksi dan operasi bangunan. Keempat, konstruksi hijau memanfaatkan material yang tidak berbahaya untuk kesehatan manusia dan dapat diperbarui dengan cepat [1].

Salah satu material hasil dari daur ulang (recycle) adalah ecobrick. Ecobrick dapat digunakan sebagai material ramah lingkungan, baik sebagai material bangunan maupun material interior. Ecobricks dapat disatukan menggunakan karet ban bekas, silikon, plester tanah liat dan semen untuk membangun furnitur, kebun, dan elemen bangunan [12]. Dalam penggunaannya, ecobrick dapat menjadi elemen arsitektur dalam membentuk ruang. Elemen pembentuk ruang seperti dinding atau perabot seperti kursi, meja kecil dan panggung dapat dibuat menggunakan ecobrick. Penelitian ini dilakukan untuk mengkaji ecobrick sebagai material pembentuk pintu.

\section{Tinjauan Pustaka}

Pembahasan pada tinjauan pustaka mencakup arsitektur hijau yang akan berfokus kepada material arsitektur hijau yang didaur ulang (recycled). Pembahasan material daur ulang akan dikaitkan dengan ecobrik yang diterapkan pada salah satu elemen pembentuk ruang, yaitu pintu.

\subsection{Arsitektur Hijau}

Arsitektur hijau adalah sebuah konsep arsitektur yang berusaha meminimalkan pengaruh buruk terhadap lingkungan alam maupun manusia dan menghasilkan tempat hidup yang lebih baik dan lebih sehat, yang dilakukan dengan cara memanfaatkan sumber energi dan sumber daya alam secara efisien dan optimal [17]. Arsitektur hijau dapat diartikan sebagai sebuah karya rancangan urban yang memiliki hasil perancangan arsitektur yangmaksimal dengan dampak kerusakan lingkungan yang minimal [10]. 
Arsitektur hijau yang diwujudkan dalam bangunan hijau dapat dideskripsikan sebagai gerakan, yang meliputi prinsip kesadaran lingkungan. Gerakan ini berupa praktik mengubah dan menginovasi standar perancangan dan konstruksi untuk mengurangi dampak negatif pada lingkungan [16]. Arsitektur hijau meminimalkan penggunaan sumber daya alam oleh manusia untuk menjamin generasi mendatang dapat memanfaatkan sumber daya alam tersebut bagi kehidupannya kelak. Arsitektur hijau juga meminimalisir dampak negatif bangunan terhadap lingkungan di mana manusia hidup [7].

Dari beberapa teori ini, dapat disimpulkan bahwa arsitektur hijau adalah upaya atau praktik menghasilkan bangunan yang dapat meminimalisir dampak negatif terhadap lingkungan dan manusia dengan memperhatikan efisiensi penggunaan sumber daya untuk menghasilkan bangunan yang memiliki performa tinggi. Salah satu aspek penting pada arsitektur hijau adalah material. Material pada arsitektur hijau pada umumnya terdiri dari material terbarukan dan ramah lingkungan karena dampaknya dipertimbangkan selama masa pakai produk tersebut. Selain itu, material pada arsitektur hijau pada umunya menghasilkan pengurangan biaya perawatan dan penggantian selama masa pakai bangunan, menghemat energi, dan meningkatkan kesehatan dan produktivitas penghuni.

Beberapa aspek pada material arsitketur hijau yaitu:

- Material yang digunakan kembali (reused) dan daur ulang (recycled),

- Material lokal,

- Material yang berasal dari alam,

- Material yang berumur panjang,

- Material yang tidak Beracun

- Material yang dapat terdegradasi secara alami (Biodegradable).

\subsection{Material Daur Ulang}

Manfaat utama dari daur ulang untuk menghemat material mentah alami, menghemat energi, mengurangi emisi berbahaya dan mengurangi ruang yang dibutuhkan untuk tempat pembuangan akhir (TPA). Tingkat manfaat bervariasi dengan jenis material dan bentuk daur ulang [20]. Dengan mendaur ulang material, energi yagn terkandung (embodied energy) dapat dijaga. Energi yang digunakan untuk mendaur ulang sebagian besar material lebih sedikit dibandingkan energi yang dibutuhkan untuk membuat material asli [8].

Beberapa indikator dari kajian teori pada pembahasan material daur ulang (recycle) adalah

- Penggunaan energi yang lebih sedikit dibandingkan memproduksi material baru.

- Penghematan material mentah.

- Mengurangi limbah yang dibuang ke tempat pembuangan akhir (TPA).

\subsection{Ecobrick}

Ecobrick merupakan material daur ulang dari sampah plastik. Ecobrick adalah bata yang dibuat dengan cara mengisi botol PET (polietilena tereftalat) dengan bahan non-biodegradable seperti plastik, bungkus kemasan, selofan, dan lainlain yang dipadatkan. Bila dipadatkan dengan tepat, ecobrick dapat digunakan berkali-kali [11]. Pembuatan Ecobrick dapat dilakukan dengan cara:

- Isi botol dengan bahan yang tidak dapat diuraikan oleh organisme alam (non-biodegradables). Material seperti plastik, busa, kemasan, dan selofan. Jangan memasukkan kertas, kaca, bahan organik dan logam tajam. Bahan organik dapat menghasilkan gas metana sehingga merusak botol

- Menggunakan tongkat untuk memadatkan botol. Untuk memaksimalkan kepadatan ecobrick, plastik dipotong hingga menjadi bagian yang lebih kecil. Plastik dengan ukuran kecil dapat menghasilkan ecobrick yang lebih padat.

- Menggunakan plastik berwarna untuk mengisi bagian bawah botol.

- Menggunakan satu jenis merek botol yang paling banyak. Hal ini untuk mempermudah konstruksi. 
Kepadatan minimal untuk ecobrick adalah 0,33 gram/mililiter. Kepadatan dapat diukur dengan cara mengukur berat ecobrick (dalam gram) dibagi dengan volume botol yang digunakan

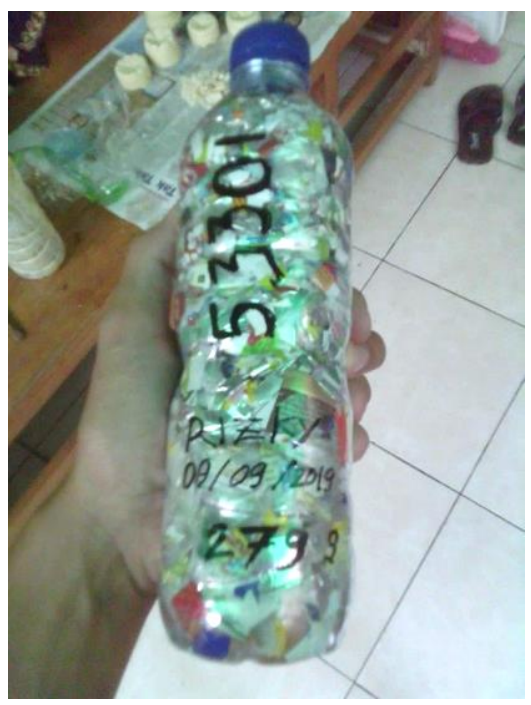

Gambar. 1. Ecobrick

Ecobrick memiliki beberapa karakteristik, yaitu:

- Ecobrick memiliki berat yang ringan [18].

- Memiliki daya tekan yang cukup bagus [18].

- Memiliki indeks reduksi suara (sound rection index) yang cukup tinggi [18].

- Tahan terhadap air [13].

- Biaya pembuatan yang murah [13].

\subsection{Elemen Pembentuk Ruang}

Secara umum, elemen pembentuk ruang dibagi menurut empat kategori sederhana: lantai, dinding, atap dan langitlangit, pengisi ruang dan perlengkapan bangunan [22]. Menurut Krier [9], beberpa elemen pembentuk ruang terdiri dari beberapa elemen seperti langit-langit, lantai, kolom, pintu, jendela, tangga dan atap. Menurut Wicaksono [21], ruang interior dibentuk oleh beberapa bidang dua dimensi, yaitu lantai, dinding, langit-langit, seta bukaan pintu dan jendela. Apablia salah satu dari elemen ini tidak ada, maka ruang tersebut tidak bisa dikatakan sebagai interior / ruang dalam. Elemen pembentuk ruang secara umum terdiri dari langit-langit, dinding, jendela, pintu, lantai, kolom, tangga.

\subsection{Elemen Pintu}

Pintu merupakan bukaan pada dinding dengan engsel atau partisi bergeser yang memungkinkan akses dari satu ruang ke ruangan lainnya [5]. Pintu berguna untuk memberikan akses menuju ruangan pada bangunan. Pintu didefenisikan sebagai pembatas yang dapat digerakkan pada bukaan dinding pada tingkat lantai . Pintu dapat dikonstruksi dengan material kayu, plywood, kaca, besi atau kombinasi dari material tersebut [3].

Menurut Ching [4], pintu memberikan akses fisik dari satu ruang ke ruang lainnya. Ketika tertutup, pintu menutup ruangan dari ruangan lain yang berbatasan dengannya. Ketika terbuka, pintu menjadi penghubung yang membentuk jalur dari satu ruangan ke ruagna lainnya. Pintu dapat mengendalikan penggunaan ruang, pandangan (view), suara, cahya, dan suhu pada ruangan. 
Dari beberapa teori ini, dapat disimpulkan bahwa pintu merupakan bagian dari elemen pembentuk ruang yang berfungsi mengubungkan antar ruang ketika dibuka dan menutup akses dari ruangan lain ketika ditutup. Pintu merupakan bukaan yang dapat diakses oleh pengguna ruang. Menurut Bechar [3], bagian utama dari pintu adalah

- Kosen (Frame)

- Daun penutup pintu (Shutter)

- Style

- Rail

- Panel

- Kisi-kisi (Louver)

- Angkur (Hold fasts)

- Sponing (Rebate)

Selain bagian daun pintu, pintu juga memiliki perlengkapan untuk menunjang fungsi pintu. Beberapa perlengkapan tersebut adalah

- Engsel

- Kunci Pintu / Kunci Pengaman

- Closer

- Bel Pintu (Doorbell) / Ketukan Pintu (Door Knocker)

- Grendel Rantai Pintu

- Kaca Lubang Intip (Door Viewers)

- Penahan Pintu (Door Bumper)

Menurut Bechar [3], berdasarkan bentuknya pintu terbagi menjadi beberapa jenis yaitu

- Pintu Langkan dan papan (Ledge and batten)

- Pintu Langkan, papan dan penguat (Ledge, batten and brace)

- Pintu Langkan, papan, dan kerangka (Ledge, batten and frame)

- Pintu Langkan, papan, penguat, dan kerangka (Ledge, batten, brace and frame)

- Pintu Panel

- Pintu Flush

- Pintu Harmonika

- Pintu Putar

- Pintu Ayun

- Pintu Rolling Shutter

- Pintu Berkisi-kisi (Louver)

\section{Metodologi}

Metode yang digunakan pada penelitian ini adalah kualitatif. Proses pengumpulan data dilakukan dengan cara observasi dan dokumentasi. Dalam pengumpulan data, bahan penilaian berdasarkan parameter yang didapat dari indikator pada variabel penelitian. Studi literatur dikumpulkan untuk mendapatkan kesimpulan teori yang dirumuskan menjadi variabel. Variabel yang telah ditentukan digunakan untuk mengkaji hasil observasi. Pengkajian hasil observasi akan menghasilkan evaluasi yang akan digunakan untuk membahas permasalahan dan tujuan penelitian. Observasi dilakukan terhadap proses pembuatan ecobrick dan pembuatan pintu. Hasil observasi yang telah dikaji mendapatkan 
kesimpulan agar didapatkan evaluasi ecobrick sebagai pembentuk elemen pintu. Evaluasi hasil penelitian akan menghasilkan kesimpulan.

\section{Pembahasan}

\subsection{Pintu Ecobrick}

Bagian pintu yang digunakan adalah rail, style, panel, engsel, kunci pintu. Jenis pintu berdasarkan bentuk adalah pintu panel. Terdapat delapan panel yang digunakan pada pintu. Pada bagian panel, terdiri dari kayu penopang ecobrick yang memiliki lebar sesuai dengan diameter ecobrick, Hal ini menghasilkan panel yang lebih lebar dibandingkan bagian style dan rail. Ukuran pintu.adalah 80 x $209 \mathrm{~cm}$. Dengan ketebalan $3 \mathrm{~cm}$ dan $7 \mathrm{~cm}$ pada bagian panel.

Pintu beroperasi dengan cara berayun. Hal ini untuk menyesuaikan kosen yang sudah ada pada ruangan yang akan digunakan pintu. Bahan pintu secara keseluruhan menggunakan kayu sebagai kerangka pendukung dan ecobrick sebagai pengisi panel. Terdapat material lain seperti besi pada bagian engsel, kunci pintu, gagang pintu, dan sekrup yang mengikat pada kunci pintu dan engsel. Pembuatan pintu dilakukan setelah pembuatan ecobrick yang dibutuhkan selesai dibuat. Waktu pengerjaan pintu adalah 3 hari. Pembuatan pintu mencakup penambahan kayu sebagai penopang panel ecobrick dan penambahan kawat sebagai penahan ecobrick.

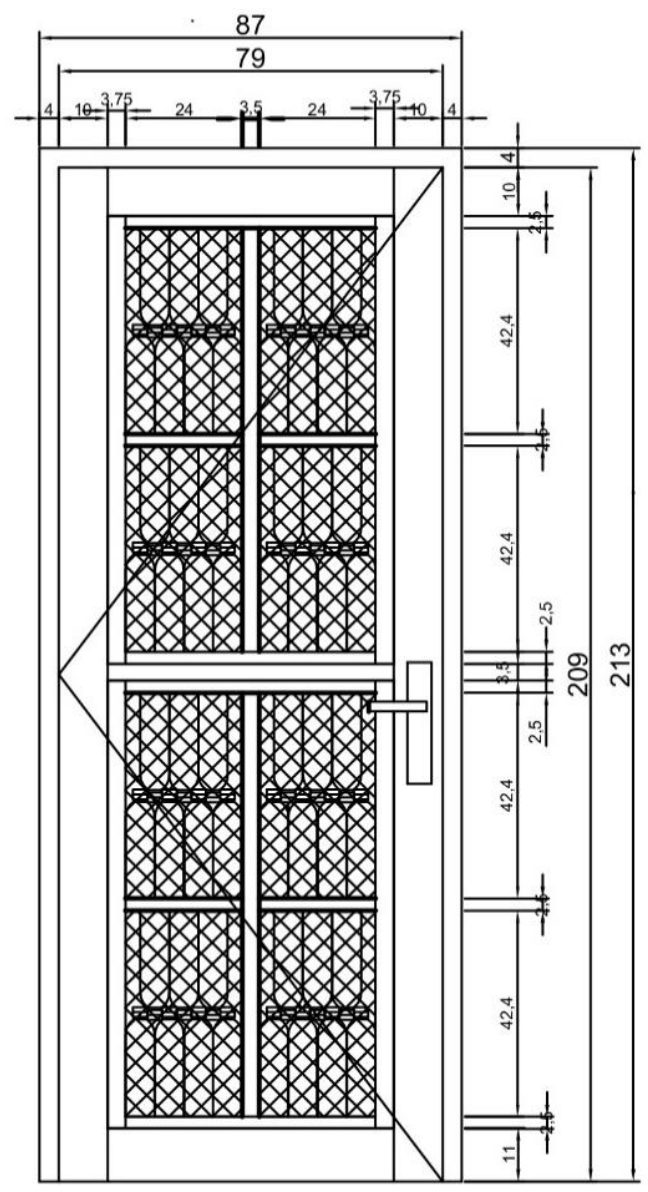

(a). Dimensi Pintu Ecobrick

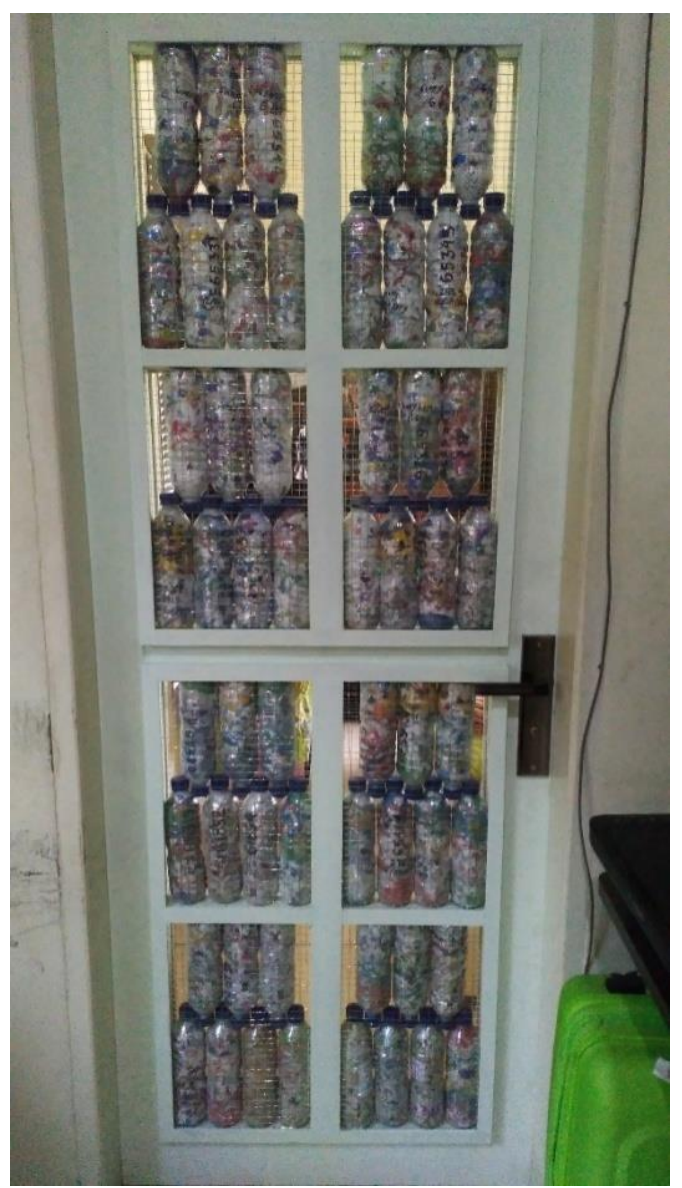

(b). Pintu Ecobrick 
Bagian pintu terdiri dari beberapa bagian, yaitu Kerangka kayu, ecobrick sebagai bahan pengisi panel, dan bahan pendukung.

\subsection{Karangka Kayu}

Bingkai kayu bekas digunakan pada pembuatan pintu. Penggunaan bingkai kayu bekas bertujuan untuk mempercepat pengerjaan konstruksi pintu dan menggunakan kembali (reuse) material yang masih berfungsi dengan baik. Kerangka kayu pada bagian tengah dibuat oleh pengrajin kayu untuk memperkuat panel ecobrick. Kerangka kayu ini merupakan rail dan style pada pintu.
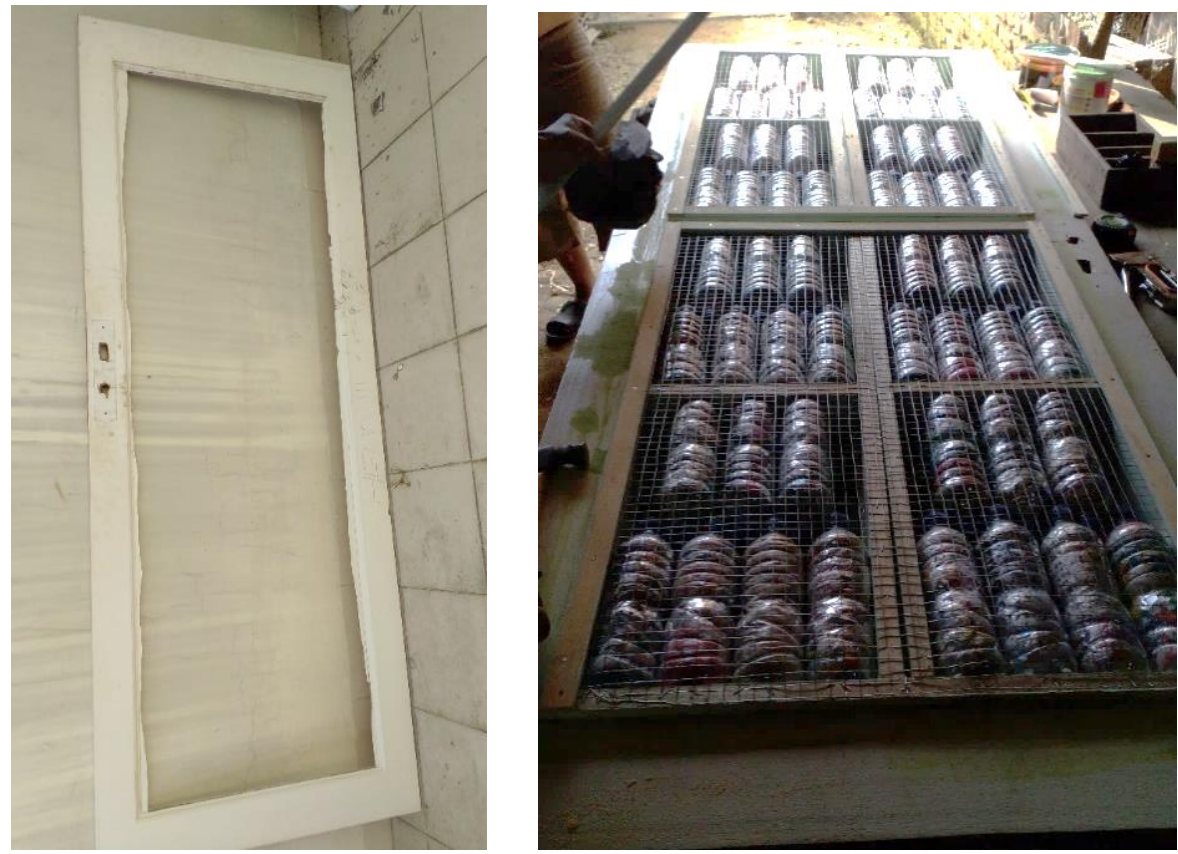

Gamabar. 3. Kerangka Kayu

\subsection{Ecobrick}

Ecobrick merupakan bahan pengisi pada panel. Penempatan ecobrick diperkuat oleh kerangka kayu yang berfungsi sebagai style dan rail. Pada setiap panel, membutuhkan 7 botol ecobrick yang disusun saling mengunci antara kepala botol yang satu dengan yang lainnya. Tujuh botol disusun dengan cara 4 botol menghadap ke atas dan 3 botol menghadap ke bawah seperti pada gambar 3. Bagian dasar ecobrick yang bersentuhan dengan kerangka kayu dipaku untuk memperkuat panel.

Berat total ecobrick yang digunakan yaitu 15522 gram atau 15, 522 kilogram. Berat rata-rata ecobrick yang digunakan yaitu 277,1786 gram. Semua ecobrick yang digunakan melebihi kepadatan minimal yang diperlukan yaitu 0,33 gr/ml. Rata-rata kepadatan ecobrick yang digunakan adalah $0,46 \mathrm{gr} / \mathrm{ml}$. Berat total dari pintu ecobrick adalah $33 \mathrm{~kg}$. Berat keseluruhan ecobrick berdasarkan adalah 15,22 kg. Persentase ecobrick pada pintu berdasarkan berat pintu adalah $47 \%$. 


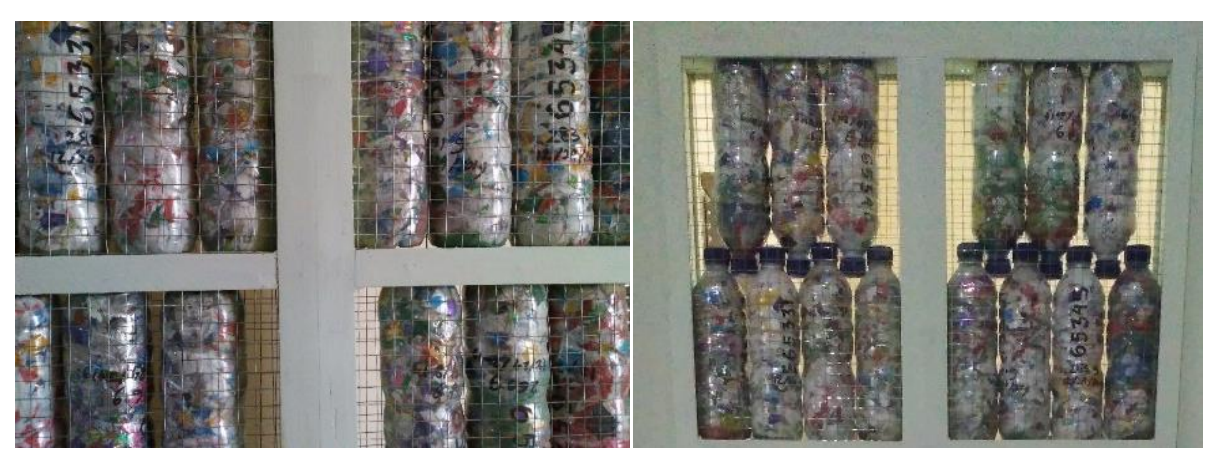

Gambar. 4. Ecobrick pada pintu

\section{Bahan Pendukung}

Bahan pendukung pada pintu merupakan bahan tambahan pada pintu. Beberapa bahan pendukung yaitu pegangan pintu, kunci dan engsel pintu. Total engsel yang dibutuhkan pada pintu yaitu empat engsel. Engsel ditambah untuk menopang berat pintu.
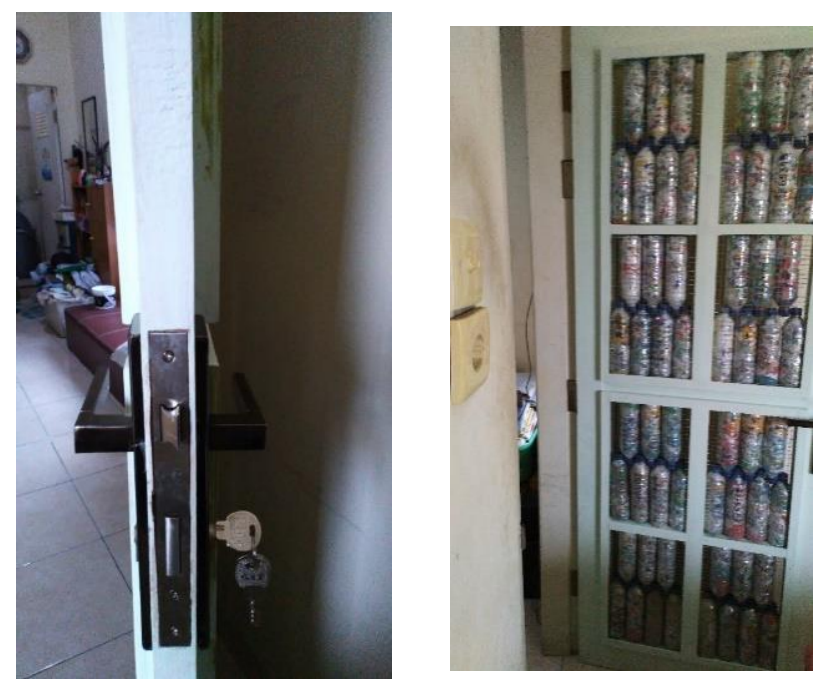

(a) Kunci Pintu (b) Penggunaan empat engsel

Gambar. 5. Bahan Pendukung pada pintu

\subsection{Perbandingan Pintu Ecobrick Pintu Panel Kayu}

Pintu ecobrick akan dibandingkan dengan pintu kayu, karena pintu ecobrick padapenelitian ini menggunakan material kayu pada bingkai. Dalam penelitian ini, bentuk pintu mendekati bentuk pintu ecobrick yang dibuat pada penelitian ini merupakan pintu panel. 


\subsection{Pembuatan Pintu}

Waktu pembuatan pintu memiliki waktu yang relatif sama, yaitu sekitar 2 hingga 3 hari. Pembuatan pintu ecobrick lebih rumit dibandingkan pembuatan pintu kayu, dikarenakan tidak adanya standar prosedur pembuatan pintu eocbrick dibandingkan pintu kayu.

\subsection{Karakteristik Pintu}

Bagian yang digunakan, pada pintu panel, baik pintu ecobrick maupun pintu panel kayu adalah style, rail, panel, engsel, kunci pintu. Perbedaan pada pintu panel kayu dan pintu ecobrick terdapat pada ukuran panel. Pada pintu panel kayu, panel memiliki ketebalan yang lebih tipis. Sedangkan pada pintu ecobrick, panel memiliki ketebalan yang lebih tebal berdasarkan diameter botol ecobrick.

Pintu ecobrick dan pinti panel kayu dapat beroperasi dengan cara berayun. Pada pintu ecobrick berat pintu dapat mencapai $33 \mathrm{~kg}$, sedangkan pada pintu panel kayu berat pintu sekitar $17 \mathrm{~kg}$. Pintu ecobrick membutuhkan engsel yang lebih banyak untuk menopang berat pintu pada kosen. Ukuran pintu ecobrick dan pintu panel kayu memiliki dimensi panjang dan lebar yang sama, namun memiliki perbedaan pada ketebalan pada panel.

\subsection{Biaya Pembuatan Pintu}

Biaya pintu Ecobrick membutuhkan total Rp 893,000,- Dengan perincian Rp 393,000,- pada bahan tambahan selain bingkai kayu bekas dan ecobrick. Bingkai kayu bekas dan ecobrick disediakan oleh penulis sedangkan material lainnya dibeli lagi oleh pengrajin sesuai dengan kebutuhan pembuatan pintu. Biaya upah pekerja.yaitu Rp 500,000,.-Terdapat kendala membandingkan harga pada pintu kayu dengan pintu ecobrick dikarenakan bentukan pintu yang berbeda dan terdapat variasi harga pintu berdasarkan kayu yang digunakan. Berdasarkan informasi dari pengrajin, beberapa harga pintu kayu berdasarkan harga satuan yaitu:
1. Pintu Kayu Sembarang
$\operatorname{Rp} 400,000,-$
2. Pintu Kayu Meranti
$\operatorname{Rp} 750,000,-$
3. Pintu Kayu Merbau
$\operatorname{Rp} 1,000,000,-$

\section{Kesimpulan}

Plastik dapat memberikan manfaat pada masa penggunaannya, namun memiliki dampak yang buruk ketika plastik menjadi limbah dan tidak dikelola secara tepat. Plastik dianggap sebagai sampah karena tidak dapat gunakan. Memberikan manfaat pada plastik dapat dilakukan melalui daur ulang. Daur ulang dapat dilakukan dengan pembuatan ecobrick. Penerapan material daur ulang merupakan salah satu aspek pada arsitektur hijau, sehingga ecobrick sebagai hasil daur ulang dari limbah plastik dapat digunakan sebagai elemen arsitektur dalam membentuk pintu.

Penggunaan ecobrick pada pintu dapat menggunakan cukup banyak sampah plastik sehingga dapat mengurangi jumlah sampah plastik. Pintu dengan material ecobrick juga menghasilkan bentukan pintu yang unik jika dibandingkan dengan pintu panel kayu, sehingga memiliki nilai lebih pada estetika bentuk pintu. Ecobrick memiliki bentuk yang tetap sesuai dengan botol yang digunakan. Sehingga merubah ukuran ecobrick dilakukan dengan mengganti ukuran botol yang digunakan. Ecobrick bersifat modular sehingga penyesuaian bentuk dilakukan pada bagian bingkai penahan ecobrick.

Penggunaan banyak sampah plastik juga berdampak pada pintu yang semakin berat. Hampir setengah dari berat total pintu merupakan berat dari ecobrick. Hal ini disebabkan karena ecobrick tidak dapat dibentuk secara bebas. Pintu membutuhkan penopang yang kokoh untuk menahan berat dari ecobrick pada bagian panel. Biaya bahan ecobrick relatif murah dibandingkan dengan material pintu lainnya, namun biaya terbesar pada pembuatan pintu ecobrick terdapat pada kerangka penopang panel. Ecobrick dapat menjadi alternatif bahan pembentuk pintu yang unik, namun belum 
sepenuhnya sesuai jika penggunaan ecobrick bertujuan komersil. Diperlukan alternatif desain dan bahan pendukung ecobrick untuk memaksimalkan penggunaan ecobrick.

\section{Referensi}

[1] Baker, Michael J., et al. (2010) "Green Materials and Construction" di The Law of Green Buildings: Regulatory and Legal Issues in Design, Construction, Operations, and Financing. Chicago: American Bar Association

[2] Barnes, D.K.A, et al. (2009) "Accumulation and fragmentation of plastic debris in global environments." Phil. Trans. R. Soc. B.364(1526): 19851998.

[3] Bechar, Rakesh Ranjan. (2005) "Basic Civil Engineering”. New Delhi: Laxmi Publication

[4] Ching. Francis. D. K. (1996) “Ilustrasi Desain Interior.” Terjemahan oleh Paul HanotoAdjie. Jakarta: Erlangga

[5] Davies, Nikolas, Erkki Jokiniemi. (2011) “ Architect's Illustrated Pocket Dictionary.” Oxford: Elsevier

[6] Kaza, Silpa, et al. (2018) "What a Waste 2.0 : A Global Snapshot of Solid Waste Management to 2050. Urban Development." Washington: World Bank.

[7] Karyono, Tri Harso. (2014) “Green Architecture: Pengantar Pemahaman Arsitektur Hijau di Indonesia”. Jakarta: Rajawali Press

[8] Kim, Jong-Jin, Brenda Rigdon. (1998) "Sustainable Architecture Module: Qualities, Use, and Example of Sustainable Buildings Materials." Ann Arbor: National Pollution Prevention Center for Higher Education

[9] Krier, Rob. (1988)“Komposisi Arsitektur.” Terjemahan oleh Effendi Setiadarma. 2001. Jakarta: Erlangga

[10] Kusumawanto, Arif, Zulaikha Budi Astuti. (2018) Arsitektur Hijau dalam Inovasi Kota. Yogyakarta: UGM Press

[11] Maier, Russell, Irene Angway. (2015) Vision Ecobricks Guide. Tersedia pada https://www.ecobricks.org

[12] Maier, Russell, Irene Angway. (2017) The Vision Ecobricks Construction Guide. Tersedia pada https://www.ecobricks.org

[13] Manisha. (2017) "Investigating Strength and Properties of Ecolandrilos : Ecobrick." International Journal of Civil Engineering and Technology (IJCIET).8 (7): 134-142

[14] PlasticsEurope. (2008) "The compelling facts about plastics, analysis of plastics production, demand and recovery for 2006 in Europe" di https://www.plasticseurope.org/application/files/2815/1689/9283/2006compelling_fact_PubJan2008.pdf (akses 26 September 2019)

[15] Ragheb, Amany, et al. (2015) “Green Architecture: A Concept of Sustainability.” Procedia - Social and Behavioral Sciences. 216(2016): 778-787

[16] Stempler, Mark J., Daniel A. Dorfman. (2014) "Green Building 101" di Green Building and the Construction Lawyer: a Practical Guide to Transactional and Litigation Issues. Chicago: American Bar Association

[17] Sudarwani, M Marai. (2012) "Penerapan Green Architecture dan Green Building Sebagai Upaya Pencapaian Sustainable Architecture." Dinamika Sains Universitas Pandanaran. 10 (24)

[18] Taffe, Jonathan, et al. (2014) "Experimental characterisation of Polyethylene Terephthalate (PET) bottle Eco-bricks." Materials and Design. 60: $50-56$

[19] Thompson, Richard C., et al. (2009) "Plastics, the environment and human health: current consensus and future trends.” Phil. Trans. R. Soc. B. 364 (1526): 2153-2166

[20] Thormark, Catarina. (2000) "Environmental Analysis of a Building with Reused Building Materials". International Journal of Low Energy and Sustainable Buildings. Vol 1

[21] Wicaksono, Andrie A, Endah Tisnawati. (2014) “Teori Interior.” Jakarta: Griya Kreasi

[22] Wiryomartono, Bagoes. (2016) “Komposisi Arsitektur: Apresiasi dan Analisis Kasus di Indonesia.” Jakarta: Erlangga

Webb, Hayden K., et al. (2013) "Plastic Degradation and Its Environmental Implications with Special Reference to Poly(ethylene terephthalate).

Polymers." 5(1): 1-18 